\title{
Aeolian dust inputs in the Mediterranean and Black Sea marine system
}

\author{
Kotinas V.A.* and Poulos S.E. \\ ${ }^{1}$ Laboratory of Physical Geography, Section of Geography and Climatology, Department of Geology and Geoenvironment, National \& \\ Kapodistrian University of Athens, Panepistimioupolis - Zografou, 15784, Attiki, Greece \\ Received: 16/06/2021, Accepted: 23/07/2021, Available online: 15/08/2021 \\ *to whom all correspondence should be addressed: e-mail: vkotinas@geol.uoa.gr \\ https://doi.org/10.30955/gnj.003819
}

\section{Graphical abstract}

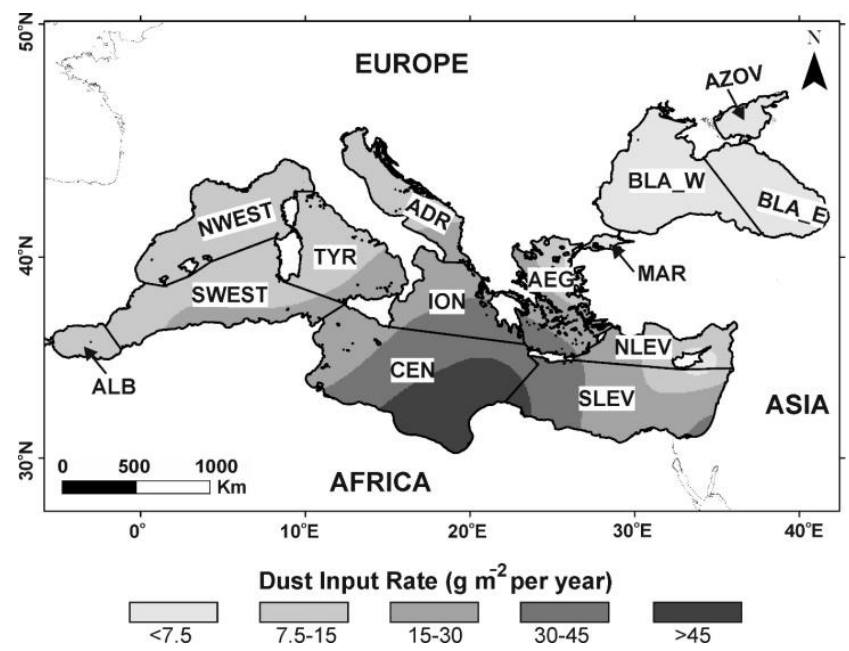

Abstract

The aim of this paper is to estimate the amount of aeolian dust, tansferred by dry and wet processes, that is deposited to the eleven marine regions of the Mediterranean-Black Sea Marine System (MBMS) and to compare it to the riverine influxes (i.e. suspended and dissolved sediment loads). This research is based on information for aeolian dust deposition at several coastal stations, around the MBMS, following an extended research of the available literature. For data elaboration, processing, and visualization a G.I.S. environment was utilized. The total annual amount of dust input for the whole system has been estimated to $59.9 \times 10^{6}$ tonnes, of which $57.2 \times 10^{6}$ tonnes are deposited in the Mediterranean Sea and only $2.7 \times 10^{6}$ tonnes in the Black Sea. The contribution of dust input (load), corresponding to $6.2 \%$ and $0.8 \%$ of the total amount of suspended and dissolved load, for the Mediterranean and Black Sea respectively, reveals the significant role of the aeolian dust inputs to the MBMS marine environment, in particular, at its southern Mediterranean domain.

Keywords: Marine Regions, Sahara dust, dust load, sediments.

\section{Introduction}

According to the "Glossary of Atmospheric Chemistry Terms" (IUPAC, 1990) dust is defined as "Small, dry, solid particles projected into the air by natural forces, such as wind, volcanic eruption, and by mechanical or man-made processes such as crushing, grinding, milling, drilling, demolition, shoveling, conveying, screening, bagging, and sweeping. Dust particles are usually in the size range from about 1 to $100 \mu \mathrm{m}$ in diameter, and they settle slowly under the influence of gravity. Atmospheric dust particles are removed from the atmosphere through three processes: (a) dry deposition, where the particles are deposited directly to the earth's surface (mainly through aerodynamic transport and or Brownian transport); (b) wet deposition, where the material is transferred by precipitation to the ground; and (c) cloud deposition, which is less important, than the other two processes and involves the movement of material that is trapped in nonprecipitating droplets of clouds or fog (Lovett, 1994).

The presence of dust in the atmosphere can affect the temperature of the atmosphere and ocean through the process of absorption and scattering of solar radiation by dust particles (e.g. Alpert et al., 1998; Miller and Tegen, 1998; Yue et al., 2010). Dust may also affect marine biological processes by providing valuable nutrients (Jickells et al., 1998). Although the fertilizing potential of atmospheric deposition on ocean production in the Mediterranean is a matter of debate, the coupling between dust deposition and the annual chlorophyll-a cycle can, on average, account for $11.5 \%$ of the total of nutrients (Gallisai et al., 2012). Similarly, Kalinskaya and Varenik (2019) have reported cases of dust transport over the Black Sea associated with high concentrations of inorganic phosphorus and silicon. Moreover, Rahav et al. (2020) have shown that cyanobacteria (i.e. Prochlorococcus) biomass, may be attributed, at least to some extent, to the impact of bio-aerosol deposition related to dust emissions in the case of oligotrophic "LowNutrients\&Low-Chlorophyll-a" regions such as that of the Mediterranean basin. 
The scope of this work is to estimate the amount of aeolian dust being transferred by the atmosphere to the various marine regions of the Mediterranean-Black Sea Marine System (MBMS), through wet and dry processes, and to compare dust inputs to the suspended and dissolved sediment fluxes.

\section{Mediterranean and Black Sea marine system}

The Mediterranean Sea and the Black Sea comprise a semi-enclosed intercontinental marine system (i.e., MBMS: Mediterranean and Black Marine System), bordered by the Eurasian and African continents, having a total surface of circa $3 \times 10^{6} \mathrm{~km}^{2}$. The MBMS includes the three Mediterranean basins (Carter et al., 1972) i.e. Western, Centre, Eastern Mediterranean (WMED, CMED, EMED) and the Black Sea (BLS), which are subsequently divided into 11 marine regions (Cruzado, 1985; Ludwig et al., 2010; Poulos and Kotinas, 2020; UNEP, 2012), as characteristically shown in Figure 1.

The basins of the Mediterranean and Black Sea receive a non-negligible amount of aeolian inputs compared to the riverine sediment fluxes. For example, the annual rate of aeolian sediment supply (mostly Saharan dust) for the Aegean Sea is of the order of $10-40 \mathrm{~g} \mathrm{~m}^{-2}$ (Nihlén and Olsson, 1995) that corresponds to a total dust deposition of 1.5-6.5 x $10^{6} \mathrm{t}_{\text {year }}^{-1}$ (Poulos, 2009) when the total of suspended and dissolved load equals to $48 \times 10^{6} \mathrm{t}_{\text {year }}{ }^{-1}$ (Poulos, 2019). The principal natural source of aeolian dust in the case of MBMS is the Sahara Desert (covering an area of about $9.2 \times 10^{6} \mathrm{~km}^{2}$ ) while a secondary source is the Arabian desert (spanning over an area of circa 1.85 $\times 10^{6} \mathrm{~km}$ ). In the case of the Black Sea and in particular at its eastern part additional sources of aeolian dust are the Central Asia deserts: the Kyzyl-Kum $\left(0.30 \times 10^{6} \mathrm{~km}^{2}\right)$; Karakum $\left(0.35 \times 10^{6} \mathrm{~km}^{2}\right)$; and the Aralkum $\left(0.04 \times 10^{6}\right.$ $\left.\mathrm{km}^{2}\right)$.

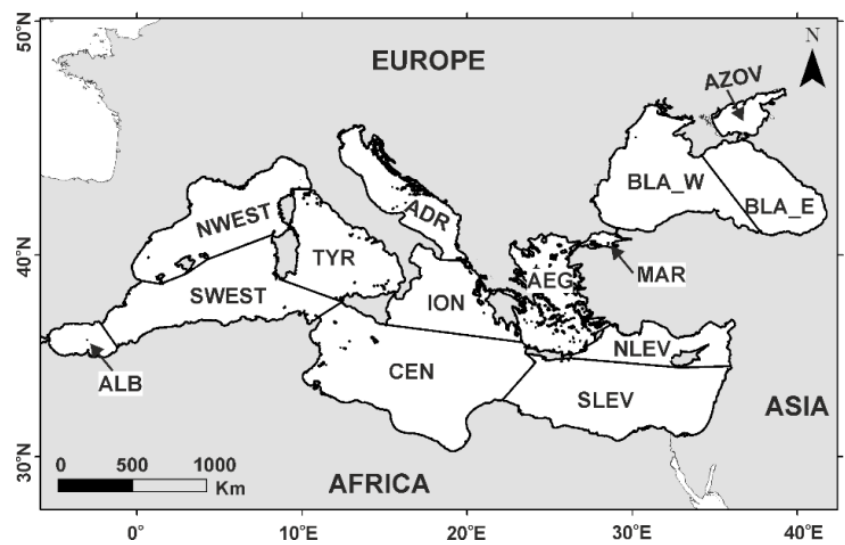

Figure 1. The Mediterranean and Black Sea marine system (ALB: Alboran, WEST: West MED (North \& South marine basins), TYR: Tyrrhenian, ADR: Adriatic, ION: Ionian, CEN: Centric MED, LEV: Levantine (North \& South marine basins), AEG: Aegean, MAR:

Marmara, BLA: Black Sea (West \& East marine basins) and finally AZOV: Azov Sea.

Most of the northward dust transportation across the MBMS (mainly affecting the Mediterranean but reaching also the Black Sea) is related to the southerly winds (Scirocco, Ghibili, Khamsin), which are associated with seasonal displacement of cyclones over the Mediterranean (e.g. Rodriguez et al., 2001). Maximum dust transport is observed during spring over the central and eastern parts of the Mediterranean (Luck and Ben Othman, 2002; O'Hara et al., 2006). During summer, when anticyclonic conditions are prevalent, and drought characterizes the Mediterranean area (e.g. BoutRoumazeilles et al., 2013; Israelevich et al., 2012; Roberts et al., 2008), significant amounts of dust can be transported from the Sahara desert by the aforementioned southerly winds. Moreover, the transportation of dust to the eastern part of the Black Sea is associated with easterly /southeasterly winds related to the low- and mid-tropospheric flows from the Caspian Central Asia regions in the east and warm advection from the Middle East in the south (Davitashvili, 2019). In general, the dust transport occurs in the form of "pulses", and the annual dust flux can be controlled by a few episodes, with several researchers (e.g. Barnaba and Gobbi, 2004; Pey et al., 2003) reporting that a single Sahara outbreak can account for $40-80 \%$ of the total annual flux.

The relative contribution of dry or wet deposition to dust inputs is determined by the rainfall regimes, which are highly variable in this region. For instance, in the eastern Mediterranean, the relative contribution of dry deposition can reach $93 \%$ of the total dust input during summer (Kubilay et al., 2000), whereas in the north-west of the Mediterranean wet deposition is prevalent (Vincent et al., 2015).

\section{Materials and methods}

The observed rates of dust deposition (wet and dry) in several stations of the study area (obtained from several researchers; see Table 1) were imported into a geodatabase. In Table 1 the mean observed rates of dust deposition at coastal stations of the MBMS system are listed. Most of these stations cover periods that are longer than 2 years of continuous field measurement but in the case of the Black Sea, where measurements are limited, stations with shorter duration of measurements were available.

The values presented in Table 1 , are within the same order of magnitude with the values reported by other researchers; for example, Guerzoni and Molinaroli (2005) have given annual values of 2-25 $\mathrm{g} \mathrm{m}^{-2}$ and 6-46 $\mathrm{g} \mathrm{m}^{-2}$ for the WMED and EMED, respectively. On the other hand, the values of Table 1 are one to two orders of magnitude higher than those simulated for MED by Gallisai et al. (2012), using the BSC-DREAM8b model for the period January 2000 - December 2007: 0.18-0.36 $\mathrm{g} \mathrm{m}^{-2}$ year ${ }^{-1}$ (southern part) and 0.007-0.01 $\mathrm{g} \mathrm{m}^{-2}$ year-1 (northern part). These differences can be attributed to the fluctuations of frequency and intensity of the recorded dust events for different time periods and to the data (average monthly values) utilised in mathematical simulations.

For the estimation of the dust inputs for each marine region of the MBMS the point data of Table 1 were imported in G.I.S. as points, wherein Thiessen polygons 
were created, and a natural neighbour interpolation (Sibson, 1981) was used to calculate the spatial distribution of dust in the MBMS (grid size $1 \times 1 \mathrm{~km}$ ), followed by the calculation of total dust load for each of the marine regions. The algorithm behind the interpolation method (also known as "Sibson" or "areastealing" interpolation) finds the closest subset of input samples (Okabe et al., 2000) to a query point and after applying weights, based on proportionate areas, it interpolates a value. The algorithm uses only a subset of samples that surround a point of interest, and the interpolated values are within the range of the samples Table 1. Dust deposition rate (wet and dry) around the MBMS used for the interpolation. The calculated surface is smooth and free of discontinuities and trends (e.g. peaks, pits). Also, this method doesn't require to make statistical assumptions, can be applied to very small datasets as it is not statistically based (Etherington, 2020) and, finally, it is parameter free (no input parameters are required). As a result of these properties this interpolation technique is well suited for the interpolation of continuous variables for which only a limited set of data points with highly irregular spatial distribution are available (Hofstra et al., 2008), like in our case.

\begin{tabular}{|c|c|c|c|}
\hline Location & Dust $\left(\mathrm{g} \mathrm{m}^{-2} \mathrm{yr}^{-1}\right)$ & Period & Reference \\
\hline Lanjaron (S Spain) & 11.1 & 2001-2002 & Morales-Baquero et al. (2006) \\
\hline Montseny (NE Spain) & 5.2 & $1983-1994$ & Avila et al. (1997) \\
\hline Palma de Baleares (E Spain) & $\sim 14$ & $1982-2003$ & Fiol et al. (2005) \\
\hline Cap Ferrat (SE France) & 11.4 & $2003-2007$ & Ternon et al. (2010) \\
\hline \multirow{2}{*}{ Capo Carbonara (SE Sardenia) Sardinia (2 sites) } & 12.8 & 1990-1992 & Guerzoni et al. (1999) \\
\hline & 9.8 & 1990/91/93 & Le Bolloch et al. (1996) \\
\hline \multirow{2}{*}{ Capo Cavallo (NW Corsica) } & 12.5 & $1985-1986$ & Bergametti et al. (1989) \\
\hline & 9.7 & $1986-1987$ & Remoudaki (1990) \\
\hline Lemnos Island (N Aegean Sea) & 11.2 & & Nihlén and Olsson (1995) \\
\hline Mytilene (NE Aegean) & 5.4 & 2001-2002 & Guieu et al. (2010) \\
\hline Crete (S. Aegean) & 36.4 & $1989-1990$ & Nihlén et al. (1995) \\
\hline Erdemili (SE Turkey) & 13 & 1991-1992 & Kubilay et al. (2000) \\
\hline Cavo Greco (Cyprus) & 4.2 & 2001-2002 & Guieu et al. (2010) \\
\hline Varna (E Bulgaria) & 4.9 & 2009 & Theodosi et al. (2013) \\
\hline Azov Sea (Russia) & 36 & $2009-2013$ & Sorokina and Soier (2016) \\
\hline Sinop (N. Turkey) & 1.9 & 2009 & Theodosi et al. (2013) \\
\hline Haifa, Israel & $\sim 36$ & $1992-1995$ & Herut and Krom (1996) \\
\hline Alexandria (N Egypt) & 20.3 & 2001-2002 & Guieu et al. (2010) \\
\hline North Libya (14 sites) & 58 & $2000-2001$ & O'Hara et al. (2006) \\
\hline Mahdia (E Tunisia) & 23.3 & $2001-2002$ & Guieu et al. (2010) \\
\hline Cap Spartel (NW Morocco) & 7.2 & 2001-2002 & Guieu et al. (2010) \\
\hline
\end{tabular}

It has also to be noted that there is an uncertainty caused by either the inaccuracy of the measured mean annual value (mainly attributed to the small duration of the measurements), and/or the inherent error of the interpolation technique. Assuming that mean dust input for each site is accurately representative, in order to estimate the inaccuracy introduced by the interpolation method a cross validation method was applied: through an iterative procedure we excluded all sites, through rotation (one sample at a time), followed by the calculation of a new interpolated surface for the new data set (Ghosh et al., 2012; Joseph et al., 2013). The estimated dust input value of the omitted point, for each rotation, was then compared with the observed value and a series of measurements of accuracy where calculated: (a) mean absolute error (MAE) and (b) root mean squared error (RMSE).

\section{Discussion}

The dust load (DUL), expressed in tonnes per year, for each of the marine regions of the MBMS (as shown in Figure 1) was calculated and is presented against the riverine sediment fluxes (SSL \& DL) that are derived from the literature (SSL: suspended sediment load, DL: dissolved sediment load (Table 2)).

Dust deposition in the Mediterranean ranges between < $0.1 \times 10^{6} \mathrm{t}$ year ${ }^{-1}$ (Sea of Marmara), to $26 \times 10^{6} \mathrm{t} \mathrm{year}^{-1}$. The dust inputs for the Black Sea are generally $<1 \times 10^{6} \mathrm{t}_{\text {year }}{ }^{-1}$, with the exception of the Azov marine region (approx. 1.5 $\times 10^{6} \mathrm{t}$ year ${ }^{-1}$ ); this increased value is most probably related to the dust inputs of its surrounding flat area, and its proximity to the central and eastern Asian deserts.

On an annual basis, the Mediterranean basin receives $57.17 \times 10^{6}$ tonnes of dust and the Black Sea $2.71 \times 10^{6}$ tonnes, which corresponds to $6.2 \%$ and $0.8 \%$ to their riverine inputs (suspended and dissolved load), respectively (Table 2 ). It has to be mentioned that in the 
case of the Centric Mediterranean marine basin dust contribution is 1.5 times higher than the contribution of riverine inputs ( $S S L+D L)$; this is explained by the absence of significant riverine inputs and the proximity of this marine region to the Libyan coast, where the highest concentrations of aeolian dust form Sahara have been monitored. The accuracy of the estimates derived from the applied interpolation method (MAE $=2.68$ and RMSE $=1.5$ ) are relatively low (although adequately) compared to the range of the values that were used for the interpolation (Table 1), and in all cases the absolute error was less than $25 \%$.

The overall spatial distribution (Figure 2) of dust inputs presents a W-E zonal distribution with values decreasing northwards. Therefore, aeolian dust inputs are expected to play a crucial role in bio-geo-chemical cycles at the southern parts of the central and eastern oligotrophic Mediterranean Sea (Kress et al., 2003; Poulos, 2020; UNEP/MAP, 2010), where the highest dust inputs occur and this work can help other researchers in marine or environmental studies.

Table 2. Catchment area (CA in $\mathrm{km}^{2}$ ) and annual estimates of suspended sediment load (SSL), dissolved sediment load (DL), Dust load (DUL) and the ratio between DUL and the sediment load (SSL+DL) for the marine regions of the Mediterranean and Black Seas Marine System (see also Figure 1)

\begin{tabular}{|c|c|c|c|c|c|c|c|}
\hline \multirow{2}{*}{ Marine Basin } & Area $^{1}$ & Dust rate & DUL & $S_{S L} L^{2}$ & $\mathrm{DL}^{2}$ & SSL+DL & DUL/ (SSL+DL) \\
\hline & $\mathrm{km}^{2}$ & $\left(\mathrm{~g} \mathrm{~m}^{-2} \mathrm{yr}^{-1}\right)$ & \multicolumn{4}{|c|}{$\times 10^{6}$ tonne } & (\%) \\
\hline ALB & 54,173 & 10.09 & 0.55 & 21.1 & 11.7 & 32.8 & 1.67 \\
\hline WEST & 573,340 & 12.87 & 7.38 & 150.1 & 61.7 & 211.8 & 3.48 \\
\hline NWEST & 261,240 & 12.52 & 3.27 & 85.7 & 37.6 & 123.3 & 2.65 \\
\hline SWEST & 312,100 & 13.17 & 4.11 & 64.4 & 24.1 & 88.5 & 4.64 \\
\hline TYR & 217,497 & 11.03 & 2.40 & 62.5 & 25.7 & 88.2 & 2.72 \\
\hline WMED & 845,010 & 11.57 & 9.78 & 233.7 & 99.1 & 332.8 & 2.94 \\
\hline ADR & 140,320 & 10.01 & 1.40 & 196 & 52.09 & 248.09 & 0.57 \\
\hline ION & 173,493 & 23.38 & 4.06 & 80.6 & 21.4 & 102 & 3.98 \\
\hline CEN & 616,527 & 42.17 & 26.00 & 10.6 & 6.1 & 16.7 & 155.68 \\
\hline CMED & 930,340 & 33.82 & 31.46 & 287.2 & 79.59 & 366.79 & 8.58 \\
\hline LEV & 552,100 & 21.71 & 11.98 & 151.6 & 15.18 & 166.78 & 7.19 \\
\hline NLEV & 138,126 & 13.48 & 1.86 & 25.9 & 8.8 & 34.7 & 5.37 \\
\hline SLEV & 413,974 & 24.45 & 10.12 & 125.7 & 6.38 & 132.08 & 7.66 \\
\hline AEG & 192,026 & 20.21 & 3.88 & 28.6 & 19.3 & 47.9 & 8.10 \\
\hline MAR & 11,887 & 5.23 & 0.06 & 2.1 & 2.1 & 4.2 & 1.48 \\
\hline EMED & 756,013 & 21.07 & 15.93 & 182.3 & 36.58 & 218.88 & 7.28 \\
\hline MED & $2,531,363$ & 22.58 & 57.17 & 703.2 & 215.27 & 918.47 & 6.22 \\
\hline BLA_W & 261,013 & 3.65 & 0.95 & 138.2 & 129 & 267.2 & 0.36 \\
\hline BLA_E & 161,221 & 1.69 & 0.27 & 28.4 & 15.6 & 44 & 0.62 \\
\hline BLA & 422,235 & 2.90 & 1.23 & 166.6 & 144.6 & 311.2 & 0.98 \\
\hline AZOV & 41,274 & 36 & 1.49 & 18.8 & 16 & 34.8 & 4.27 \\
\hline BLS & 463,509 & 5.85 & 2.71 & 185.4 & 160.6 & 346 & 0.78 \\
\hline MBMS & $2,994,872$ & 19.99 & 59.88 & 888.6 & 375.87 & 1264.47 & 4.74 \\
\hline
\end{tabular}

${ }^{1}$ From Poulos and Kotinas (2020)

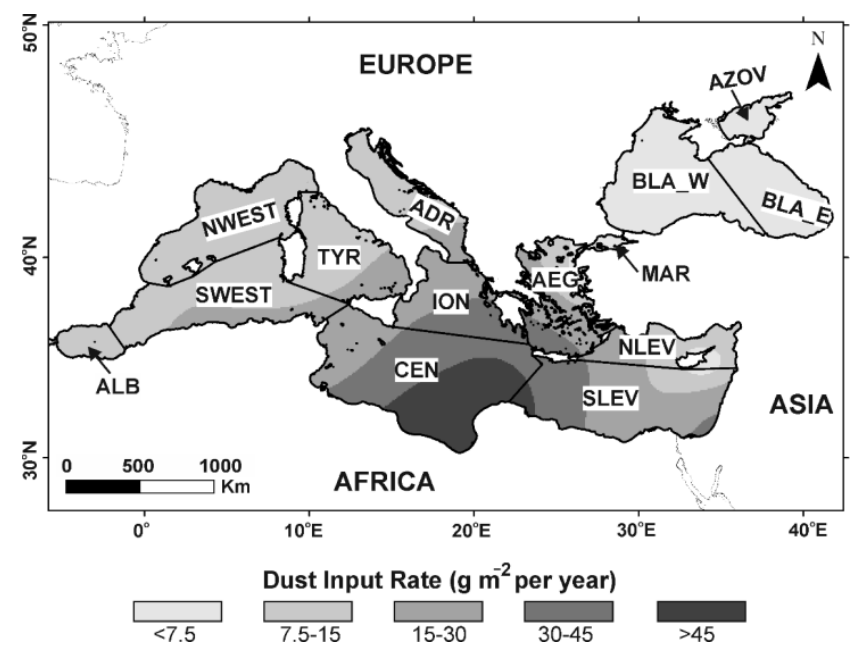

Figure 2. Indicative Spatial distribution of the rate of dust inputs in the Mediterranean and Black Sea marine system (MBMS).

\section{Conclusions}

The MBMS is estimated to receive $59.9 \times 10^{6}$ tonnes of aeolian dust per year, from which $57.2 \times 10^{6}$ tonnes are settled in the Mediterranean Sea (MED) marine region and $2.7 \times 10^{6}$ tonnes in the Black Sea (BLS) marine region. The central part of the Mediterranean (CMED) receives about $55 \%$ of the total dust load of the whole MED due to its proximity with the Sahara Desert, while the Black Sea (BLS) receives very small amounts of aeolian dust.

Dust inputs (dry and wet), mostly of Saharan origin, cannot be ignored in environmental studies (i.e. biological productivity, sedimentation), regarding the Mediterranean Sea (primarily) and the Black Sea 
(secondarily), as they represent a significant percentage (almost 5\%) to their total terrestrial influxes.

\section{Acknowledgements}

The authors acknowledge the Special Account for Research Grants of the National \& Kapodistrian University of Athens (Research code: 70/4/15859)

\section{References}

Alpert P., Kaufman Y.J., Shay-El Y., Tanre D., Da Silva A., Schubert S. and Joseph J.H. (1998). Quantification of dust-forced heating of the lower troposphere. Nature, 395, 367-370. https://doi.org/10.1038/26456

Avila A., Queralt-Mitjans I. and Alarcón M. (1997). Mineralogical composition of African dust delivered by red rains over northeastern Spain. Journal of Geophysical Research, 102, 21977-21996. https://doi.org/10.1029/97JD00485.

Barnaba F. and Gobbi G.P. (2004). Aerosol seasonal variability over the Mediterranean region and relative impact of maritime, continental and Saharan dust particles over the basin from MODIS data in the year 2001. Atmospheric, Chemistry and Physics, 4, 2367-2391.

Bergametti G., Gomes L., Remoudaki E., Desbois M., Martin D. and Buat-Ménard P. (1989). Present transport and deposition patterns of African dusts to the north-western Mediterranean. In: Leinen M. and Sarnthein M. (Eds.), Paleometeorology: Modern and past patterns of global atmospheric transport (pp. 227-252). Dordrecht: Kluwer.

Bout-Roumazeilles V., Combourieu-Nebout N., Desprat S., Siani G., Turon J.L. and Essallami L. (2013). Tracking atmospheric and riverine terrigenous supplies variability during the last glacial and the Holocene in central Mediterranean. Climate of the Past, 9, 1065-1087. https://doi.org/10.5194/cp-91065-2013.

Carter G.T., Flanagan J.P., Jones C.R., Marchant F.L., Murhinson R.R., Rebman J.H., Sylvester J.C. and Whitney J.C. (1972). A new bathymetric chart and physiography of the Mediterranean Sea. In: Stanley D.J. (Ed.), The Mediterranean sea: a natural sedimentation laboratory (pp. 1-23). Stroudsburg, Pennsylvania: Dowden, Hutchinson and Ross.

Cruzado A. (1985). Chemistry of Mediterranean waters. Pergamon Press.

Davitashvili T. (2019). Modelling transportation of desert dust to the South Caucasus using WRF Chem model. In: E3S Web of Conferences (Vol. 99, p. 03011). EDP Sciences.

Etherington T.R. (2020). Discrete natural neighbour interpolation with uncertainty using cross-validation error-distance fields. Peer J Computer Science. https://doi.org/10.7717/peerjcs.282

Fiol L.A., Fornós J.J., Gelabert B. and Guijarro J.A. (2005). Dust rains in Mallorca (western Mediterranean): their occurrence and role in some recent geological processes. Catena, 63, 64-84. https://doi:10.1016/j.catena.2005.06.012.

Gallisai R., Peters F., Basart S. and Baldasano J.M. (2012). Mediterranean basin-wide correlations between Saharan dust deposition and ocean chlorophyll concentration. Biogeosciences Discussions, 9(7), 8611-8639.

Ghosh S., Gelfrand A.E. and Mlhave T. (2012). Attaching uncertainty to deterministic spatial interpolations. Statistical Methodology, 9(1-2), 251-264. https://doi.org/ 10.1016/ j.stamet.2011.06.001.
Goudie A.S. and Middleton N.J. (2001). Saharan dust storms: nature and consequences. Earth-science Reviews, 56(1-4), 179-204.

Guerzoni S. and Molinaroli E. (2005). Input of Various Chemicals Transported by Saharan Dust and Depositing at the Sea Surface in the Mediterranean Sea. In: Saliot A. (Ed.), The Mediterranean sea. Handbook of environmental chemistry (Vol. 5K). Heidelberg: Springer, Berlin. https://doi.org/10.1007/b107149.

Guerzoni S., Molinaroli E., Rossini P., Rampazzo G., Quarantotto G., De Falco G. and Cristini S. (1999). Role of desert aerosol in metal fluxes in the Mediterranean area. Chemosphere, 39, 229-246, https://doi:10.1016/S0045-6535(99)00105-8.

Guieu C., Loÿe-Pilot M.D., Benyahya L. and Dufour A. (2010). Spatial variability of atmospheric fluxes of metals ( $\mathrm{Al}, \mathrm{Fe}, \mathrm{Cd}$, $\mathrm{Zn}$ and $\mathrm{Pb}$ ) and phosphorus over the whole Mediterranean from a one year monitoring experiment: biogeochemical implications. Marine Chemistry, 120, 164-178, https://doi:10.1016/j.marchem.2009.02.004.

Herut B. and Krom M. (1996). Atmospheric input of nutrients and dust to the SE Mediterranean. In: S. Guerzoni and R. Chester (Eds.), The impact of desert dust across the Mediterranean (pp. 349-358). Dordrecht: Kluwer.

Hofstra N., Haylock M., New M., Jones P. and Frei C. (2008). Comparison of six methods for the interpolation of daily, European climate data. Journal of Geophysical Research, 113, D21110. https://doi.org/10.1029/2008JD010100.

Israelevich P., Ganor E., Alpert P., Kishcha P. and Stupp A. (2012). Predominant transport paths of Saharan dust over the Mediterranean Sea to Europe. Journal of Geophysical Research Atmospheres, 117. https://doi.org/10.1029/2011JD 016482.

IUPAC. (1990). Glossary of atmospheric chemistry terms. International union of pure and applied chemistry, applied chemistry division, commission on atmospheric chemistry. Pure and Applied Chemistry, 62(11), 2167-2219.

Jickells T.D., Dorling S., Deuser W.G., Church T.M., Arimoto R. and Prospero J.M. (1998). Air-borne dust fluxes to a deep water sediment trap in the Sargasso Sea. Global Biogeochemical Cycles, 12(2), 311-320.

Joseph J., Sharif H.O., Sunil T. and Alamgir H. (2013). Application of validation data for assessing spatial interpolation methods for 8-h ozone or other sparsely monitored constituents. Environmental Pollution, 178, 411-418. https://doi:10.1016/ j.envpol.2013.03.035.

Kalinskaya D.V. and Varenik A.V. (2019). The research of the dust transport impact on the biogeochemical characteristics of the Black Sea surface layer. In: 25th international symposium on atmospheric and ocean optics: atmospheric physics (Vol. 11208 , p. 1120845). International Society for Optics and Photonics.

Kress N., Manca B.B., Klein B. and Deponte D. (2003). Continuing influence of the changed thermohaline circulation in the eastern Mediterranean on the distribution of dissolved oxygen and nutrients: Physical and chemical characterization of the water masses. Journal of Geophysical Research C: Oceans, 108(C9), 8109. https://doi.org/10.1029/2002JC001397.

Kubilay N., Nickovic S., Moulin C. and Dulac F. (2000). An illustration of the transport and deposition of mineral dust onto the eastern Mediterranean. Atmospheric Environment, 34, 1293-1303. doi: 10.1016/S1352-2310(99)00179-X. 
Le Bolloch O., Guerzoni S. and Molinaroli E. (1996). Atmosphereocean mass fluxes at two coastal sites in Sardinia. In: S. Guerzoni and R. Chester (Eds.), The impact of desert dust across the Mediterranean (pp. 217-222). Dordrecht: Kluwer.

Lovett G.M. (1994). Atmospheric deposition of nutrients and pollutants in north america: an ecological perspective. Ecological Applications, 4(4), 629-650. https://doi.org/10.2307/1941997.

Luck J.M. and Ben Othman D. (2002). Trace element and Pb isotope variability during rainy events in the NW Mediterranean: constraints on anthropogenic and natural sources. Chemical Geology, 182(2-4), 443-460. https://doi.org/10.1016/S0009-2541(01)00324-2.

Ludwig W., Bouwman A.F., Dumont E. and Lespinas F. (2010). Water and nutrient fluxes from major Mediterranean and Black Sea rivers: past and future trends and their implications for the basin-scale budgets. Global Biogeochemical Cycles, 24(4).

Miller R.L. and Tegen I. (1998., Climate response to soil dust aerosols. Journal of Climate, 11(12), 3247-3267.

Morales-Baquero R., Pulido-Villena E. and Reche I. (2006). Atmospheric inputs of phosphorus and nitrogen to the southwest Mediterranean region: Biogeochemical responses of high mountain lakes. Limnology and Oceanography, 51, 830-837. https://doi:10.4319/lo.2006.51.2.0830.

Nihlén T. and Olsson S. (1995). Influence of eolian dust on soil formation in the Aegean area. Zeitschrift für Geomorphologie, 39(3), 341-361.

Nihlén T., Mattsson J.O., Rapp A., Gagaoudaki C., Kornaros G. and Papageorgiou J. (1995). Monitoring of Saharan dust fallout on Crete and its contribution to soil formation. Tellus B: Chemical and Physical Meteorology, 47B, 365-374. https://doi.org/10.3402/ tellusb.v47i3.16055.

O'Hara S.L., Clarke M.L. and Elatrash M.S. (2006). Field measurements of desert dust deposition in Libya. Atmospheric Environment, 40, 3881-3897. https://doi: 10.1016/j.atmosenv.2006.02.020.

Okabe A., Boots B., Sugihara K. and Chiu S.N. (2000). Spatial Tessellations: concepts and applications of Voronoi diagrams (2nd edition). Chichester: John Wiley \& Sons

Pey J., Querol X., Alastuey A., Forastiere F. and Stafoggia M. (2003). African dust outbreaks over the Mediterranean Basin during 2001-2011: PM10 concentrations, phenomenology and trends, and its relation with synoptic and mesoscale meteorology. Atmospheric, Chemistry and Physics, 13, 13951410.

Poulos S. and Kotinas V. (2020). Physio-geographical characteristics of the marine regions and their catchment areas of the Mediterranean Sea and Black Sea marine system. Physical Geography. https://doi:10.1080/02723646. 2020.1762960.

Poulos S.E. (2009). Origin and distribution of the terrigenous component of the unconsolidated surface sediment of the Aegean floor: A synthesis. Continental Shelf Research, 29(16), 2045-2060.

Poulos S.E. (2019). River systems and their water and sediment fluxes towards the marine regions of the Mediterranean Sea and Black Sea earth system. An overview. Mediterranean Marine Science, 20(3), 549-565.

Poulos S.E. (2020). The Mediterranean and Black Sea Marine System: An overview of its physico-geographic and oceanographic characteristics. Earth-Science Reviews, 200, 103004

Rahav E., Paytan A., Mescioglu E., Bar-Zeev E., Martínez Ruiz F., Xian P. and Herut B. (2020). Bio-aerosols negatively affect prochlorococcus in oligotrophic aerosol-rich marine regions. Atmosphere, 11(5), 540.

Remoudaki E. (1990). Etude des processus contrôlant la variabilité temporelle des flux atmosphériques de polluants et de poussières minérales en Méditerranée occidentale (Thèse de doctorat). Univ. Paris 7, 244 pp.

Roberts N., Jones M.D., Benkaddour A., Eastwood W.J., Filippi M.L., Frogley M.R., Lamb H.F., Leng M.J., Reed J.M., Stein M., Stevens L., Valero-Garcés B. and Zanchetta G. (2008). Stable isotope records of Late Quaternary climate and hydrology from Mediterranean lakes: the ISOMED synthesis. Quaternary Science Reviews, 27(25-26). https://doi.org/10.1016/j.quascirev.2008.09.005.

Rodriguez S., Querol X., Alastuey A., Kallos G. and Kakaliagou O. (2001). Saharan dust contributions to PM10 and TSP levels in Southern and Eastern Spain. Atmospheric Environment, 35(14), 2433-2447.

Sibson R. (1981). A brief description of natural neighbor interpolation. In: V. Barnett (Ed.), Interpreting multivariate data (pp. 21-35). Chichester West Sussex New York: Wiley.

Sorokina V.V. and Soier V.G. (2016). Dry and wet atmospheric deposition of organic carbon in coastal and water areas of the northeastern part of the Sea of Azov. Oceanology, 56, 733-741, https://doi.org/10.1134/S0001437016040111.

Ternon E., Guieu C., Loÿe-Pilot M.D., Leblond N., Bosc E., Gasser B., Miquel J.-C. and Martín J. (2010). The impact of Saharan dust on the particulate export in the water column of the North Western Mediterranean Sea. Biogeosciences, 7, 809826. https://doi:10.5194/bg-7-09-2010.

Theodosi C., Stavrakakis S., Koulaki F., Stavrakaki I., Moncheva S., Papathanasiou E., Sanchez-Vidal A., Koçak M. and Mihalopoulos N. (2013). The significance of atmospheric inputs of major and trace metals to the Black Sea. Journal of Marine Systems, 109-110, 94-102. https://doi.org/ 10.1016/j.jmarsys.2012.02.016.

UNEP/MAP. (2012). State of the Mediterranean marine and coastal environment. Athens: UNEP/MAP - Barcelona Convention, Athens 2012, 92p.

UNEP-MAP RAC/SPA. (2010). In: Bazairi H., Ben Haj S., Boero F., Cebrian D., De Juan S., Limam A. Rais C. (Eds.), The Mediterranean Sea Biodiversity: state of the ecosystems, pressures, impacts and future priorities. RAC/SPA, Tunis, pp. 100. http://www.rac-spa.org/sites/default/files/doc_cop/bio diversity.pdf.

Vincent J., Laurent B., Losno R., Nguyen E.B., Roullet P., Sauvage S., Chevaillier S., Coddeville P., Ouboulmane N., Di Sarra A.G., Tovar-S'nchez A., Sferlazzo D., Massanet A., Triquet S., Baquero R.M., Fornier M., Coursier C., Desboeufs K., Dulac F., and Bergametti G. (2016). Variability of mineral dust deposition in the western Mediterranean basin and southeast of France. Atmospheric Chemistry and Physics, 16, 8749-8766. https://doi.org/10.5194/acp-16-8749-2016. 